\title{
Samlet fremstilling
}

\author{
af Frank Christensen
}

\author{
Helge Larsen: Dansk Idræt \\ - en tusindfryd. \\ Grundbog $i$ \\ idrætssociologi.
}

Det var med stor appetit, at jeg gav mig i gang med Helge Larsens bog om dansk idræt. Det er jo ikke hver dag, der udkommer en samlet fremstilling inden for dette emneområde.

Af bogens titel fremgår, at det er en grundbog i idrætssociologi. Desværre indeholder varen ikke hvad emballagen lover. En grundbog i idrætssociologi må på en systematisk måde stille spørgsmål og give (klare) svar, desuden må der være nogle krav til teori og metode. Dette kan bogen ikke leve op til.

I forordet kommer man da også i tvivl om forfatterens intentioner. Han skriver: 'Det har været min ambition både at udarbejde en undervisningsorienteret grundbog og en debatbog. Undervisning i emnet Idræt og Samfund har efter min opfattelse normalt været baseret på tilfældigt forhåndenværende materiale, hvilket er uacceptabelt. Oplevelsen af behovet for en debatbog, der udgør et arbejdsmateriale, har således været min motivation.'

Jeg nævner dette fra starten, fordi vurderingen af en bog hænger uløseligt sammen med de forventninger, man som læser har, når man køber bogen.

Bogens titel: 'Dansk Idræt - en tusindfryd' lever dog til fulde op til hvad den lover: - det er en sand tusinde fryd, der bliver behandlet i bogen. Bogen er en glimrende debatbog med det sigte at beskrive idrætten i Danmark ud fra en kritisk synsvinkel.

Bogen er inddelt $i$ to hovedafsnit, hvor det forste afsnit beskriver og diskuterer idrættens organisation i dagens Danmark. Det andet afsnit belyser perspektiverne inden for dansk idræt.

I første halvdel af bogen gennemgås på en pædagogisk god måde skoleidrætten, foreningsidrætten, den uorganiserede fritidsidræt og korpsidrætten.

Hvert kapitel starter med en kort indledning, der ridser de centrale spørgsmål op, og kapitlerne afsluttes med nogle diskussionsspørgsmål. 
Disse kapitler lægger på udmærket vis op til debat om idrættens organisering og indhold. Alle elever, der har læst denne første halvdel af bogen, vil være introduceret til den idrætspolitiske debat.

Jeg vil gerne fremhæve, at alle kapitlerne er struktureret således, at det kan lade sig gøre at læse hvert kapitel uafhængigt af de andre kapitler.

På den måde lever forfatteren op til sin ambition om at afhjælpe klip og klister-metoden i faget idræt og samfund.

Som følge af den manglende teori og metode, er det hele dog præget af common sense betragtninger. Den manglende sociologiske metode medfører derfor også at eleverne ikke udvikler et begrebsapparat til at forstå idrætsverdenen med.

Men når disse forbehold er taget, vil jeg gerne fremhæve, at det er en informationsrig gennemgang af idrættens organisering der foretages.

Skoleidrættens situation i dag beskrives og der foretages en sammenligning mellem idrætten inden for folkeskolen, gymnasiet, HF og EFG.

Konklusionen er, at det ikke 'står for godt til med skoleidrætten i dag. Det kniber gevaldigt med at fremme elevernes sociale udvikling, altså at opdrage dem i retning af at udvikle nogle personlighedstræk og holdninger. Skoleidrætten henter i højere grad sine holdninger i den organiserede fritidsidræts verden end i skolens verden.' (s. 23).

I afsnittet om den organiserede fritidsidræt behandler Helge Larsen dels spørgsmålet om dobbeltorganiseringen og dels spørgsmålet om konflikt eller samarbejde mellem idrætsorganisationerne. Holdningen til organisationernes funktion i samfundet er kritisk. Man kan være enig eller uenig, men kritikken lægger op til diskussion af hvilken rolle idrætsorganisationerne skal have i dag. Næste kapitel behandler den uorganiserede fritidsidræt. Kapitlet indeholder følgende overskrifter: udbredelse, den grønne bølge, livskvalitet, motiver og motionsløb, joggingbølgen og foreningslivet, narcissisme, sundhed og løb, natur og friluftsliv, Gudenå og rekreation, den sundhedspædagogiske bølge, sygdom og sundhed, baggrund, kropsopfattelse, det orientalske system, Aktiviteter og perspektiv. PA \& SIDER - PU HA. Bogens styrke og svaghed illustreres tydeligt ved denne opremsning: På den ene side vil eleverne stifte bekendtskab med en række vigtige spørgsmål til forklaring af den voldsomme stigning i den uorganiserede idrætsudøvelse, på den anden side er det nærmest kun en kalejdoskopisk oversigt over forskellige forklaringer.

Flere end nogen sinde dyrker idræt i dag , specielt uden for den organiserede idræt har der været en eksplosiv vækst.

Denne vækst er selvfølgelig et udtryk for et samfund i opbrud: økonomisk omstilling, teknologiske omvæltninger, et andet forhold til fritiden etc.

Desværre præsenteres der ikke nogen grundlæggende forklaringer på 
forandringerne $\mathrm{i}$ idrætsmønstret, derimod præsenteres en række delforklaringer som lige gode (eller om man vil lige dårlige) - og sådan forholder det sig vel ikke?

Bogens anden halvdel behandler idrætten ud fra en mere problemorienteret synsvinkel. Idrætten diskuteres udfra politiske, økonomiske, opdragelsesmæssige synsvinkler. Endvidere omtales massemediernes behandling af idrætten, samt kvindernes forhold til idrætten.

Denne anden del af bogen er på mange måder både mere konkret og mere perspektivrig. Desuden er der også en tydeligere linje i de enkelte kapitler.

Med udgangspunkt $i$ en inddeling af idrætten $i$ seks hovedgrupper: Turneringsidræt, amerikansk idræt, sundhedspædagogisk idræt, ekspressiv idræt, eksotisk idræt samt Natur og friluftsidræt diskuteres idrætten som mål eller middel.

Man kan være uenig med inddelingen, men den er god som udgangspunkt for en diskussion af, hvorfor elever dyrker idræt (eller hvorfor de ikke dyrker idræt).

En sådan diskussion vil naturligvis også føre ind $i$ en diskussion af, hvilke idrætter samfundet bør fremme.

Ligeledes bliver idrætten og økonomien også gennemgået ud fra et enkelt skema, der viser 4 områder, hvor idrætten har sine indtægtskilder: staten, kommunerne, erhvervslivet samt idrættens egenindsats. Ved hjælp af aktuelle illustrative tabeller, primært hentet fra 'betænkningen om eliteidrætten i Danmark' får man et vue over finansieringen af dansk idræt.

På denne baggrund bliver dansk idræt opdelt i 4 hovedgrupper:

1. Skoleidrætten, som det offentlige finansierer.

2. Den private kommercielle idræt, som 'klienterne' finansierer.

3. Den uorganiserede idræt og korpsidrætten som næsten udelukkende er selvfinansieret.

4. Foreningsidrætten og den kommunalt organiserede idræt der $\mathrm{i}$ betydelig grad finansieres af det offentlige.

Også denne inddeling er glimrende som udgangspunkt for en diskussion af økonomien i dansk idræt.

De følgende kapitler om idræt og opdragelse og idræt og sundhed forsøger bevidst at sætte spørgsmålstegn ved mange af idrættens myter. 
Desværre har bogen ikke de store bud på, hvordan idrætten vil udvikle sig i fremtiden, men der nævnes dog, hvilke faktorer der vil få væsentlig indflydelse.

Sammenfattende må det siges, at bogen repræsenterer den første samlede fremstilling om dansk idræt (siden betænkning $\mathrm{nr}$. 709 om idrætten og friluftslivet), og den er i sin pædagogiske form meget læsevenlig.

Bogen kan ikke benyttes som sociologisk grundbog, dertil er der for lidt struktureret sociologisk teori.

Men bogen vil kunne aflaste enhver lærer, der ønsker at undervise i emneområdet idræt og samfund. Specielt vil jeg anbefale at inddrage anden afdeling af bogen i undervisningen. 